\title{
Dietary Unsaturated Fatty Acids Increase Plasma Glucagon-Like Peptide-1 and Cholecystokinin and May Decrease Premeal Ghrelin in Lactating Dairy Cows ${ }^{1}$
}

\author{
B. J. Bradford, ${ }^{2,3}$ K. J. Harvatine, ${ }^{2,4}$ and M. S. Allen ${ }^{5}$ \\ Department of Animal Science, Michigan State University, East Lansing 48824
}

\begin{abstract}
Previous reports have indicated that dietary unsaturated fat can decrease energy intake of lactating dairy cattle. However, the mechanism for this response is unclear. To evaluate the potential role of gut peptides, periprandial concentrations of cholecystokinin (CCK), glucagon-like peptide 1 (GLP-1), and ghrelin were measured. From a replicated $4 \times 4$ Latin square experiment, 4 cows from a single square were selected for analysis of responses to 3 treatments: a control diet (5.5\% total fatty acids, $65 \%$ unsaturated), a diet with added saturated fat (SAT, $8.3 \%$ fatty acids, $47 \%$ unsaturated), and a diet with added unsaturated fat (UNS, $7.8 \%$ fatty acids, 63\% unsaturated). The SAT treatment increased duodenal flow of saturated fatty acids compared with UNS and control and, despite the fact that ruminal biohydrogenation altered fatty acid profiles of digesta, UNS increased duodenal flow of unsaturated fatty acids compared with SAT and control. Blood samples were collected at 8-min intervals through the first 2 meals of the day and analyzed by commercial radioimmunoassays. The UNS treatment increased plasma CCK concentration relative to SAT and control, and increased plasma GLP-1 concentration compared with control. Furthermore, fat treatments tended to suppress the prandial ghrelin surge that was evident for control. Suppression of feed intake by unsaturated fats is likely mediated in part by increased secretion of CCK and
\end{abstract}

\footnotetext{
Received September 5, 2007.

Accepted December 17, 2007.

${ }^{1}$ Presented in part at the American Dairy Science Association annual meeting, July 2006, Minneapolis, MN [Bradford, B. J., K. J. Harvatine, and M. S. Allen. 2006. Effect of fatty acid saturation on gut and pancreatic hormone concentrations. J Dairy Sci. 89 (Suppl. 1): 265 (Abstr.)].

${ }^{2}$ These authors contributed equally to this work.

${ }^{3}$ Current address: 127 Call Hall, Kansas State University, Manhat$\tan 66506$.

${ }^{4}$ Current address: Department of Animal Science, Cornell University, Ithaca, NY 14853.

${ }^{5}$ Corresponding author: allenm@msu.edu
}

GLP-1, and dietary fat may also inhibit ghrelin release before conditioned meals.

Key words: glucagon-like peptide 1, ghrelin, cholecystokinin, bovine

\section{INTRODUCTION}

Dietary fatty acids (FA) increase dietary energy density and provide a tempting means to modify the energy intake of animals. For example, during early lactation the dairy cow experiences an extended period of negative energy balance, and increased energy intake would be beneficial. However, increasing dietary fat has been intensely investigated for decades, with little evidence of improved energy intake by fat supplementation (Allen, 2000). Dietary unsaturated FA available in the rumen are known to interfere with ruminal fermentation, which might be responsible for the decrease in intake in response to addition of dietary fat in the dairy cow (Palmquist and Jenkins, 1980). Yet abomasal infusion of unsaturated FA (Drackley et al., 1992) and even dietary FA that are modified to prevent negative effects on ruminal fermentation (Schauff and Clark, 1992) have been shown to suppress feed intake of lactating cows.

Gut-derived peptides have attracted substantial interest in recent years as potential mediators of the intake response to supplemental dietary fat. Choi and Palmquist (1996) were the first to demonstrate that intake depression by calcium salts of long-chain FA was associated with increased release of gut peptides. Since then, a substantial number of studies have confirmed this finding (Choi et al., 2000; Benson and Reynolds, 2001; Litherland et al., 2005; Relling and Reynolds, 2007). However, only one recent report (Relling and Reynolds, 2007) has addressed the effect of FA saturation on this response.

We recently reported that shifting just $2.5 \%$ of dietary DM from saturated FA to partially unsaturated FA decreased feed intake and tended to decrease energy intake of lactating cows following $15 \mathrm{~d}$ of adaptation (Harvatine and Allen, 2006a). To better understand 
how FA alter feeding behavior, we utilized this model to investigate the effects of dietary FA and FA saturation on release of cholecystokinin (CCK), glucagon-like peptide 1 (GLP-1), and ghrelin during the periprandial period.

\section{MATERIALS AND METHODS}

Experimental procedures were approved by the AllUniversity Committee on Animal Use and Care at Michigan State University.

\section{Design and Treatments}

Experimental design, animals, and treatments have been described in detail previously (Harvatine and Allen, 2006a,b). Briefly, 8 ruminally and duodenally cannulated multiparous Holstein cows in mid-lactation were used in a duplicated $4 \times 4$ Latin square design. From this experiment, 4 cows from a single square were selected for analysis of treatment effects on periprandial concentrations of plasma hormones; due to hormone assay costs, it was only feasible to analyze 1 square. For each of these cows, plasma samples corresponding to 3 treatments were analyzed; the control diet (CON), a diet with added saturated FA (SAT, prilled, hydrogenated FA, Energy Booster 100, MSC Specialty Nutrition, Dundee, IL), and a diet with added unsaturated FA (UNS, Ca soaps of LCFA, Megalac-R, Church and Dwight Company Inc., Princeton, NJ). Diet ingredients and nutrient composition for these treatments are shown in Table 1. Diets were formulated to provide $2.5 \%$ supplemental $\mathrm{FA}$, with rice hulls added in place of FA supplements as necessary and limestone included in diets to adjust calcium concentration.

We previously reported (Harvatine and Allen, 2006d) that SAT increased flow of saturated FA to the duodenum compared with CON and UNS, whereas UNS increased flow of monounsaturated FA compared with CON and SAT (Figure 1). Treatments had no effect on duodenal flow of polyunsaturated FA because ruminal metabolism of FA resulted in significant biohydrogenation of unsaturated FA. Considering the observed reduction in feed intake by UNS (Harvatine and Allen, 2006a), these treatments were ideal for testing the specific effects of saturated and monounsaturated FA on release of hormones by the gut.

\section{Data and Sample Collection}

Throughout the experiment, cows were housed in tiestalls, fed a TMR once daily $(0900 \mathrm{~h})$ at $115 \%$ of expected daily intake, and milked twice daily. Treatment periods were $21 \mathrm{~d}$, and diets were fed for $10 \mathrm{~d}$ before collection
Table 1. Ingredients and nutrient composition of experimental diets

\begin{tabular}{|c|c|c|c|}
\hline \multirow[b]{2}{*}{ Item } & \multicolumn{3}{|c|}{ Treatment $^{1}$} \\
\hline & $\mathrm{CON}$ & SAT & UNS \\
\hline Ingredients & \multicolumn{3}{|c|}{$\%$ of diet $\mathrm{DM}$} \\
\hline Basal diet ${ }^{2}$ & 94.2 & 94.5 & 94.2 \\
\hline Ca soaps of long-chain fatty acids ${ }^{3}$ & - & - & 3.3 \\
\hline Prilled, hydrogenated fatty acids ${ }^{4}$ & - & 2.5 & - \\
\hline Rice hulls & 2.9 & 0.3 & 0.6 \\
\hline Limestone & 1.0 & 0.9 & - \\
\hline Ground corn & 1.9 & 1.8 & 1.8 \\
\hline \multicolumn{4}{|l|}{ Nutrient composition } \\
\hline $\mathrm{OM}$ & 92.6 & 92.9 & 93.1 \\
\hline Starch & 30.8 & 30.3 & 30.7 \\
\hline NDF & 29.1 & 27.3 & 27.7 \\
\hline $\mathrm{CP}$ & 16.2 & 16.1 & 16.1 \\
\hline Total fatty acids & 5.5 & 8.3 & 7.8 \\
\hline Unsaturated fatty acids ${ }^{5}$ & 3.6 & 3.9 & 4.9 \\
\hline
\end{tabular}

${ }^{1}$ Treatments are control (CON), addition of dietary saturated fatty acids (SAT), and addition of dietary unsaturated fatty acids (UNS).

${ }^{2}$ Basal diet included corn silage, alfalfa silage, ground corn, whole cottonseed, protein mix, and mineral-vitamin mix, and is described in Harvatine and Allen (2006b).

${ }^{3}$ Megalac-R, Church \& Dwight Co., Princeton, NJ.

${ }^{4}$ Energy Booster 100, MSC Specialty Nutrition, Dundee, IL.

${ }^{5}$ Fatty acid profiles of diets are detailed in Harvatine and Allen (2006d).

of blood samples and feed intake data. Amounts of feed offered and refused were weighed for each cow daily, and samples of all diet ingredients $(0.5 \mathrm{~kg})$ and refusals from each cow (12.5\%) were collected daily on $\mathrm{d} 11$ through 13 of each period for DM analysis. On d 14 of each treatment period, indwelling polypropylene catheters $(0.24 \mathrm{~cm}$ o.d. $\times 0.17 \mathrm{~cm}$ i.d. tubing, MRE 095, Braintree Scientific, Braintree, MA) were inserted through a 10-gauge needle until approximately $30 \mathrm{~cm}$ of tubing was inside the jugular vein. On d 15 of each period, blood samples were collected at 8-min intervals, beginning approximately $16 \mathrm{~min}$ before feeding $(0844 \mathrm{~h})$ and continuing through 264 min postfeeding (36 sample times). This time period was adequate for animals to complete their first (conditioned) and second (spontaneous) meals of the day. In this experiment, these 2 meals collectively accounted for approximately $20 \%$ of daily feed intake. Throughout the blood collection period, the weight of each feed manger was logged every $5 \mathrm{~s}$ for analysis of feeding behavior, as described previously (Dado and Allen, 1993). Feeding behavior during the blood collection period was quantified as eating rate $(\mathrm{kg}$ of DM consumed per cow/min) and was collapsed into 1 value per 8-min interval for statistical analysis.

To allow for normal feeding behavior during blood sample collection, blood was collected by using an automated system (Allen et al., 2000). Catheters were connected to gas-sterilized Tygon silicone tubing ( $\sim 6 \mathrm{~m}$ $\times 1.6 \mathrm{~mm}$ i.d., Fisher Scientific Co., Pittsburgh, PA) connected to programmable 4-channel peristaltic 

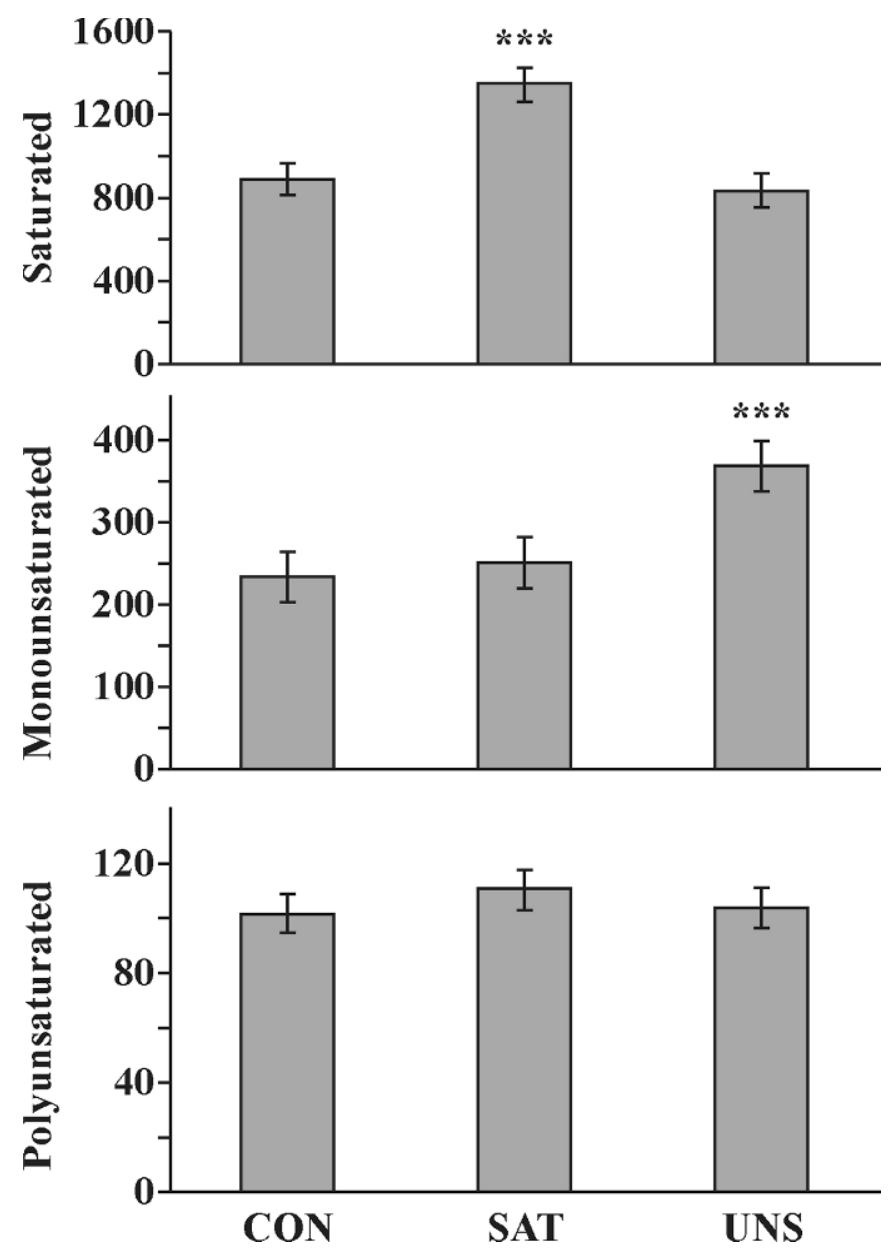

Figure 1. Duodenal flow of fatty acids (g/d). Treatments are control $(\mathrm{CON})$, addition of dietary saturated fatty acids (SAT), and addition of dietary unsaturated fatty acids (UNS). Treatment SAT increased flow of saturated fatty acids to the duodenum, while UNS increased flow of monounsaturated fatty acids (Harvatine and Allen, 2006d). Values are least squares means \pm SEM, $\mathrm{n}=8$. ${ }^{* * *}$ Different than other treatments, $P<0.001$.

pumps (\#78016-30, Cole-Parmer Instrument, Vernon Hills, IL) and fraction collectors (FC 203B, Gilson Inc., Middleton, WI). At 8-min intervals, a computer initiated a programmed routine that drew blood to waste (to clear the tubing), continued to draw blood to fill 3 collection tubes, then activated a pinch valve (\#E9830126 , Cole-Parmer Instrument), and reversed the pumps to push a sterile anticoagulant solution $(4.2 \% \mathrm{Na}$ citrate) back through the tubing and catheters. The complete routine lasted $6.5 \mathrm{~min}$, and automated collection of blood was successful for $>90 \%$ of samplings. When problems arose, catheters were disconnected from the tubing, blood was collected manually, and catheters were flushed with $5 \mathrm{~mL}$ of $4.2 \% \mathrm{Na}$ citrate solution. Blood was collected into tubes containing potassium EDTA (Vacutainer, Becton Dickinson, Franklin Lakes,
NJ) and aprotonin (Sigma Chemical Co., St. Louis, MO), and then placed on ice. Within $60 \mathrm{~min}$ of collection, samples were centrifuged at $2,000 \times g$ for $15 \mathrm{~min}$, plasma was harvested, and samples were frozen at $-20^{\circ} \mathrm{C}$ for subsequent analyses.

\section{Sample Analysis}

Diet ingredients and refusals were coarsely ground with dry ice, lyophilized (TriPhilzer MP, FTS Systems, Stone Ridge, NY), and analyzed for DM concentration. Plasma samples were analyzed to determine CCK-8, GLP-1 (7-37), and active ghrelin concentrations using commercial double-antibody RIA kits based on the principles outlined by Morgan and Lazarow (1963). Plasma CCK was assayed (\#RB302, Euro-Diagnostica, Malmö, Sweden) after ethanol extraction as suggested by the kit manufacturer. Reconstituted samples were incubated with an antibody specific for sulfated CCK-8, with crossreactivity of $<1 \%$ for human gastrin- 17 and nonsulfated forms of CCK, as reported by the manufacturer. Intraand interassay coefficients of variation $(\mathbf{C V})$ for CCK analysis were 3.3 and $4.3 \%$, respectively. Ghrelin was measured with a kit specific for octanolyated (active) ghrelin (Active Ghrelin Kit \#GHRA-88HK, Linco Research, St. Charles, MO). Immediately after thawing, plasma samples $(300 \mu \mathrm{L})$ used for ghrelin analysis were acidified with $15 \mu \mathrm{L}$ of $1 \mathrm{M} \mathrm{HCl}$, and $3 \mu \mathrm{L}$ of phenylmethylsulfonyl fluoride $(10 \mathrm{~g} / \mathrm{L})$ was added as a protease inhibitor. The intraassay CV for ghrelin analysis was $5.4 \%$, and all values were determined in a single analysis. Commercial RIA used to measure CCK-8 (Mir et al., 2000) and ghrelin (Wertz-Lutz et al., 2006) were previously validated for use in bovine plasma.

A commercial kit for human GLP-1 (7-37) was used to quantify plasma GLP-1 concentrations (\#RK-028-13, Phoenix Pharmaceuticals, Belmont, CA). Peptides were isolated from plasma by solid-phase extraction (Strata C18-E columns, Phenomenex, Torrance, CA) before analysis with the double-antibody RIA. The primary antibody provided in this kit does not cross-react with GLP-1 (7-36) or glucagon (product literature), and the GLP-1 sequence is 100\% conserved between human and bovine species. The detection limit for the assay was $1.7 \mathrm{p} M$, and because of limited sample volume, 29\% of samples fell below the detection limit. Treatment did not significantly affect the proportion of samples below the detection limit $(P=0.32$; likelihood ratio chi-square test), so samples below the limit were assigned a value of $0.85 \mathrm{p} M$ for statistical analysis, as described by Hornung and Reed (1990). The intraassay CV for GLP-1 (7-37) was $8.0 \%$, and the interassay $\mathrm{CV}$ was $9.9 \%$. 


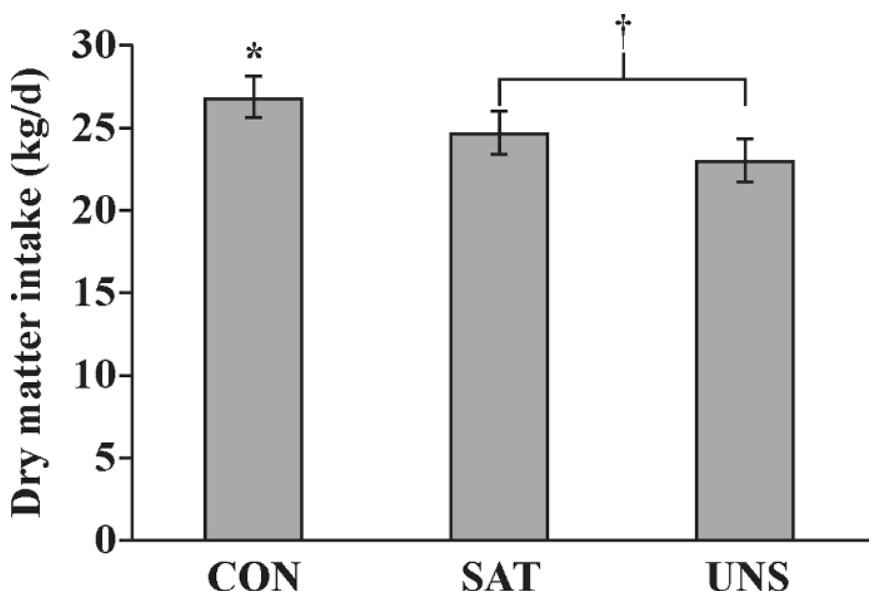

Figure 2. Dietary fat supplements decrease feed intake. Treatments are control (CON), addition of dietary saturated fatty acids (SAT), and addition of dietary unsaturated fatty acids (UNS). Values are means \pm SEM, $\mathrm{n}=4$. *Different than other treatments, $P<0.05$; $\dagger P<0.10$.

\section{Statistical Analysis}

Data were analyzed using SAS (Version 9.1, SAS Institute, Cary, NC) according to the following mixedeffects model:

$$
\mathrm{Y}_{\mathrm{ijk} \mathrm{k}}=\mu+\mathrm{P}_{\mathrm{i}}+\mathrm{D}_{\mathrm{j}}+\mathrm{C}_{\mathrm{k}}+\mathrm{T}_{\mathrm{l}}+\mathrm{DT}_{\mathrm{jl}}+\mathrm{e}_{\mathrm{ijk} \mathrm{l}}
$$

in which $Y_{i j k l}$ is a dependent variable, $\mu$ is the overall mean, $P_{i}$ is the fixed effect of period ( $i=1$ to 4 ), $D_{j}$ is the fixed effect of dietary treatment ( $\mathrm{j}=1$ to 3$), \mathrm{C}_{\mathrm{k}}$ is the random effect of cow $(\mathrm{k}=1$ to 4$), \mathrm{T}_{1}$ is the effect of sample time ( $1=1$ to 36$), \mathrm{DT}_{\mathrm{jl}}$ is the interaction of treatment and sample time, and $\mathrm{e}_{\mathrm{ijk}}$ is the residual error. Repeated measures over time were modeled with a heterogeneous autoregressive [ARH(1)] covariance structure within cow $\times$ period, and denominator degrees of freedom were estimated using the Kenward-Rogers method. When the overall treatment effect was $P<0.10$, individual treatment differences were evaluated using the pdiff option of SAS and were declared different at $P<0.05$. Ghrelin concentrations are most dynamic around the time of feeding in meal-fed ruminants (Sugino et al., 2002); therefore, treatment effects on ghrelin concentration were evaluated at a single time point using a contrast comparing FA treatments (UNS and SAT) with CON.

\section{RESULTS}

Over the $3 \mathrm{~d}$ before blood collection, both SAT and UNS depressed feed intake compared with $\mathrm{CON}(P<$ 0.05 and $P<0.01$, respectively), and UNS tended to depress feed intake relative to SAT $(P=0.08$, Figure 2 ). These results, with only the 4 cows included in the

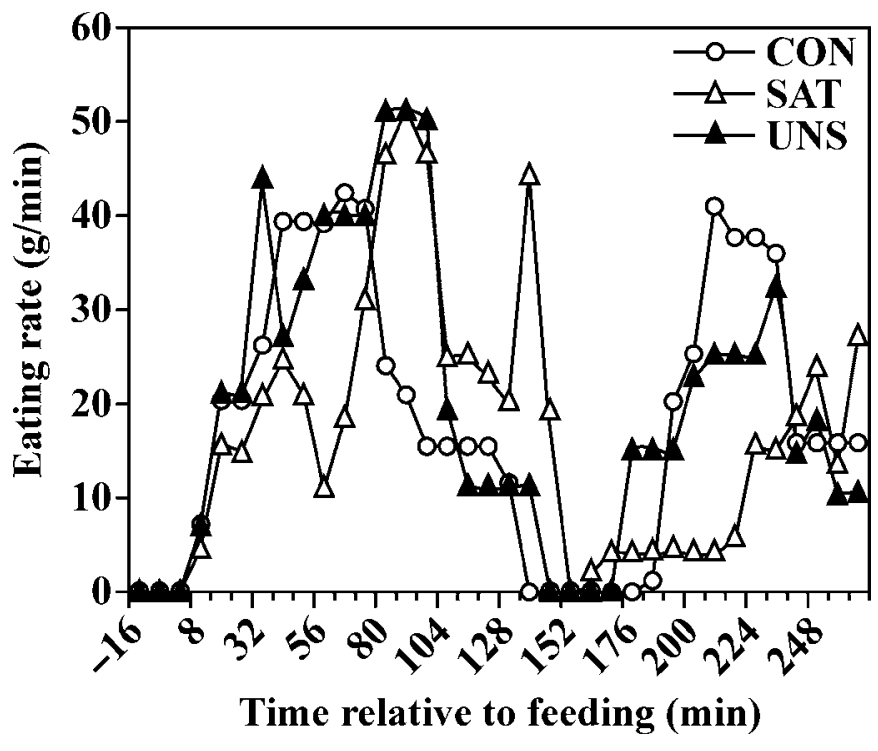

Figure 3. Effects of dietary fat supplements on eating rate through 2 meals. Treatments are control $(\mathrm{CON})$, addition of dietary saturated fatty acids (SAT), and addition of dietary unsaturated fatty acids (UNS). Values are least squares means, $\mathrm{SEM}=14.23, \mathrm{n}=4$. Effects of treatment $(P=0.94)$ and time $\times$ treatment interaction $(P=0.98)$ were not significant.

present study, were consistent with findings from the larger experiment with replicated squares (Harvatine and Allen, 2006a). However, eating rate and meal patterns were not significantly affected by treatment during the blood collection period (Figure 3), allowing for a more controlled comparison of FA effects on gut peptide release.

Plasma CCK-8 concentration was significantly increased by UNS compared with CON and SAT (Table 2 ). There was no apparent CCK-8 response to meals, and treatment differences were consistent across the sampling period (Figure 4A). The UNS treatment increased plasma GLP-1 (7-37) concentration compared with CON (Table 2). Although GLP-1 (7-37) concentrations varied significantly over time, this pulsatility did not appear to be associated with meal patterns (Figure 4B), and no time $\times$ treatment interaction was observed.

Plasma ghrelin concentrations are known to increase before meals in both ruminants and humans (Sugino et al., 2002; Cummings et al., 2004). Consistent with these observations, plasma ghrelin concentration increased around the time of feeding for CON; however, this prandial surge was not evident for SAT or UNS (Figure 4C). A contrast of FA treatments vs. CON at 8 min postfeeding demonstrated a tendency for dietary FA to suppress ghrelin release ( 8.26 vs. $15.73 \mathrm{p} M, P=$ 0.07 ). No overall treatment effect was detected for ghrelin (Table 2). 
Table 2. Effects of dietary treatments on plasma hormone concentrations through the primary and subsequent meals ${ }^{1}$

\begin{tabular}{lcccccccc}
\hline & \multicolumn{3}{c}{ Treatment $^{2}$} & & \multicolumn{3}{c}{$P$-value } \\
\cline { 2 - 4 } \cline { 7 - 9 } Hormone & CON & SAT & UNS & SEM & & Trt & Time & Trt $\times$ time \\
\hline Cholecystokinin, pM & $12.22^{\mathrm{b}}$ & $13.80^{\mathrm{b}}$ & $16.56^{\mathrm{a}}$ & 0.64 & & $<0.01$ & 0.95 & 0.41 \\
Glucagon-like peptide 1 (7-37), $\mathrm{p} M$ & $2.40^{\mathrm{b}}$ & $2.60^{\mathrm{ab}}$ & $2.97^{\mathrm{a}}$ & 0.19 & & 0.06 & $<0.001$ & 0.97 \\
Ghrelin, pM & 7.65 & 7.47 & 7.04 & 0.53 & & 0.40 & 0.11 & 0.12 \\
\hline
\end{tabular}

${ }^{\mathrm{a}, \mathrm{b}}$ Means within a row with different superscripts differ by $P<0.05$.

${ }^{1}$ Values are least squares means \pm SEM, $\mathrm{n}=4$ cows per treatment.

${ }^{2}$ Treatments (Trt) are control (CON), addition of dietary saturated fatty acids (SAT), and addition of dietary unsaturated fatty acids (UNS).

\section{DISCUSSION}

Diets containing more than $6 \%$ rumen-available fat (especially unsaturated forms) have long been known to inhibit fiber digestion by ruminal microbes (Palmquist and Jenkins, 1980), and in some cases, decrease feed intake. In an attempt to avoid this negative effect on ruminal metabolism, calcium soaps of long-chain FA were developed, and subsequent research demonstrated their efficacy (Jenkins and Palmquist, 1984). Indeed, our own findings indicate that UNS had no negative effects on ruminal digestibility of $\mathrm{OM}$, starch, or NDF compared with CON (Harvatine and Allen, 2006c). Nevertheless, calcium soaps of FA (Choi and Palmquist, 1996; Allen, 2000), and even unsaturated FA infused postruminally (Drackley et al., 1992), can depress feed intake, indicating that postruminal mechanisms are involved. Evidence presented here and elsewhere (Choi et al., 2000; Benson and Reynolds, 2001; Litherland et al., 2005; Relling and Reynolds, 2007) suggests that enhanced secretion of GLP-1 and CCK in response to unsaturated FA likely contributes to this depression of feed intake.

We did not observe meal-associated increases in plasma CCK-8 or GLP-1 (7-37) concentrations in this study; although this is somewhat surprising, this may be due to the anatomy of the ruminant digestive tract. Digesta are retained in the rumen for a long time, resulting in relatively consistent delivery of nutrients to the duodenum. In this study, the passage rate of FA from the rumen was only $\sim 7 \%$ per $\mathrm{h}$ (Harvatine and Allen, 2006d); therefore, FA consumed by ruminants can contribute to stimulation of CCK and GLP-1 release for hours after a meal ends.

The role of CCK in mediating fat-induced satiety is relatively well described (Choi et al., 2000; Beglinger and Degen, 2004); however, the effects of different classes of fats on CCK secretion have not been adequately studied. This is particularly true in the ruminant, where ruminal biohydrogenation results in duodenal flow of an array of trans-FA. Relling and Reynolds
(2007) recently reported that dietary FA supplementation increased plasma CCK-8 concentration and that unsaturated FA treatments increased CCK-8 to a greater extent than did a saturated FA treatment. We report similar findings and have published duodenal FA flow data for these treatments (Harvatine and Allen, 2006d). Likewise, consumption of oleic acid elevated CCK compared with consumption of stearic acid in humans (Beardshall et al., 1989). However, these recent findings do not agree with all past investigations into regulation of CCK by FA; several studies in both ruminants and nonruminants failed to observe specific effects of gastric or duodenal infusion of unsaturated fat on CCK concentration (Douglas et al., 1990; French et al., 2000; Benson and Reynolds, 2001; Litherland et al., 2005).

We suggest that postruminal infusion of fat sources may result in responses that differ from those induced by dietary supplementation. Although abomasal or duodenal infusion offers the advantage of controlling the delivery of fat to the duodenum, it eliminates at least 2 effects of dietary unsaturated FA: cephalic phase responses and production of trans-FA through ruminal biohydrogenation. Oral sensing of long-chain FA via CD36 has recently been reported in rats, and stimulation of this pathway caused an increase in bile flux and protein secretion by the pancreas (Laugerette et al., 2005). This novel pathway may also play a role in the stimulation of CCK release by dietary unsaturated FA, because CD36 responds preferentially to unsaturated FA (Laugerette et al., 2005), and neural control of CCK release has been demonstrated following vagotomy (Hopman et al., 1984) and sham feeding (Wisen et al., 1992). Trans-fatty acids may also be involved in stimulating CCK release; UNS increased duodenal flow of trans-C18:1 (Harvatine and Allen, 2006d), and Relling and Reynolds (2007) reported increased milk transC18:1 and plasma CCK-8 concentrations in response to dietary unsaturated FA treatments. However, in one study that directly compared postruminal infusion to dietary inclusion of canola oil (Chelikani et al., 2004), 
plasma CCK-8 concentration increased regardless of delivery method; this was despite the fact that feeding unsaturated FA increased the plasma trans-C18:1 concentration 4.4-fold. Regardless of the mechanism responsible, increased plasma CCK-8 concentration for UNS compared with SAT could help explain the decreased meal size observed for UNS (Harvatine and Allen, 2006a). Nevertheless, postruminal infusion of unsaturated fat sources can depress feed intake without elevating plasma CCK-8 (Benson and Reynolds, 2001, Litherland et al., 2005), indicating that CCK is not likely to be the sole mediator of this response.

Glucagon-like peptide 1 (7-37) is 1 of 2 active forms of GLP-1; it is thought to be released simultaneously with GLP-1 (7-36) amide and exert similar effects (Deacon, 2004). However, GLP-1 (7-36) amide is the predominant form in humans, with concentrations typically more than 4-fold greater than GLP-1 (7-37) (Deacon, 2004). The relative abundance of the 2 forms has not been previously investigated in the bovine, and the availability of a GLP-1 (7-37) antibody without crossreactivity to glucagon convinced us to measure this form of the peptide. A crude comparison of the GLP-1 (7-37) values obtained here with GLP-1 (7-36) amide concentrations reported previously for cattle (Benson and Reynolds, 2001; Litherland et al., 2005; Relling and Reynolds, 2007) suggests that the (7-36) amide form accounts for more than $90 \%$ of circulating GLP-1 in the bovine. Despite measuring the low-abundance form, we found that UNS significantly elevated the plasma concentration of GLP-1 (7-37) compared with CON. Therefore, our data are consistent with the hypothesis that elevated GLP-1 concentrations contribute to depression of feed intake by unsaturated FA (Litherland et al., 2005; Relling and Reynolds, 2007). Although we were unable to detect differences between UNS and SAT for GLP-1 (7-37) concentration, several reports have documented greater GLP-1 response to unsaturated compared with saturated FA (Thomsen et al., 1999, 2003; Rocca et al., 2001; Beysen et al., 2002; Hirasawa et al., 2005), including a study in lactating dairy cattle (Relling and Reynolds, 2007). Enhanced GLP-1 response to unsaturated FA is likely mediated by the membrane receptor GPR120; it is expressed by cells containing GLP-1 in the ileum and colon, and is activated primarily by unsaturated long-chain FA (Hirasawa et al., 2005). Furthermore, GPR120 gene knockdown by RNA interference reduced GLP-1 response to $\alpha$-linolenic acid (Hirasawa et al., 2005).

Preprandial increases in plasma ghrelin concentration are thought to contribute to hunger, with both metabolic cues (Cummings et al., 2004) and conditioned, anticipatory adaptations (Sugino et al., 2002) likely contributing to this surge. Lipids, along with

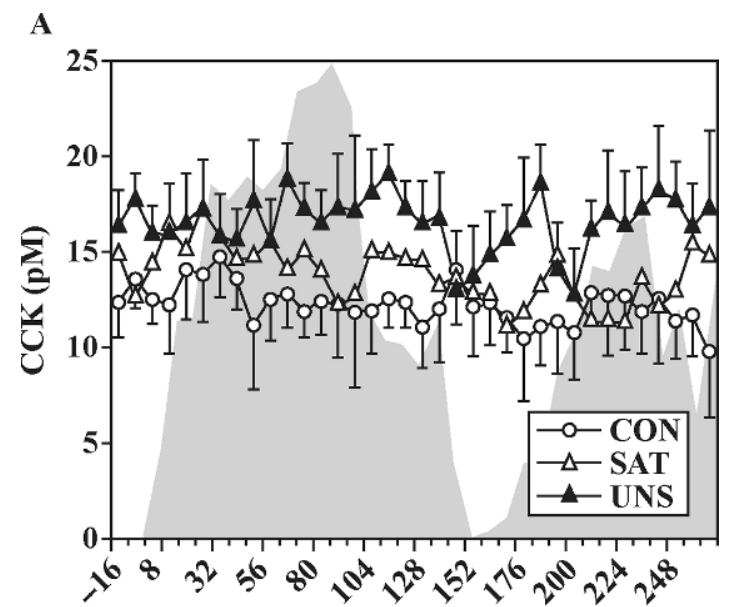

B

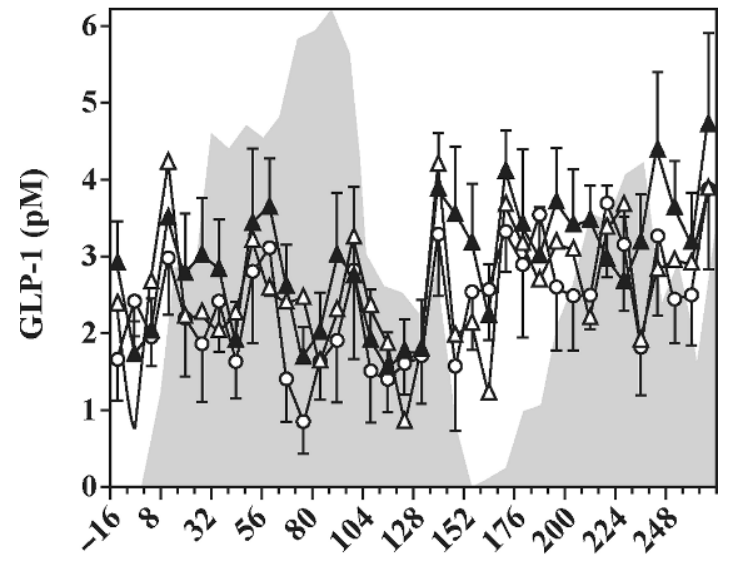

C

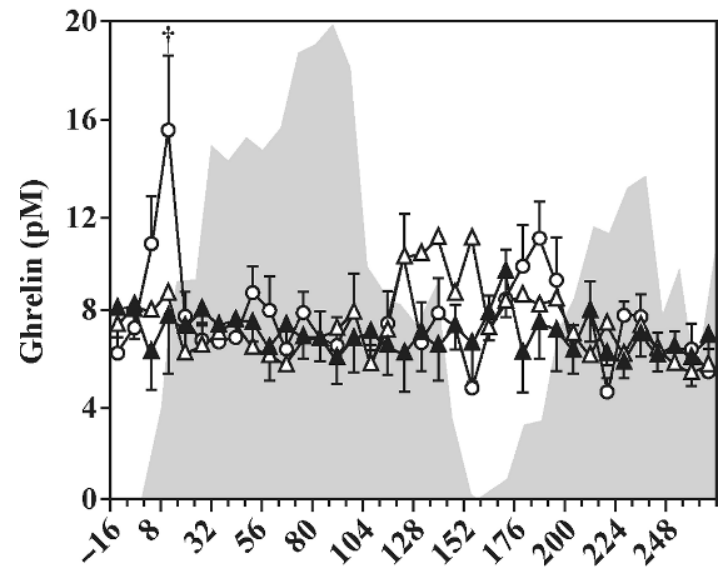

Time relative to feeding $(\mathrm{min})$

Figure 4. Dietary fat supplements alter plasma concentrations of A) cholecystokinin (CCK), B) glucagon-like peptide 1 (GLP-1), and C) ghrelin. Treatments are control (CON), addition of dietary saturated fatty acids (SAT), and addition of dietary unsaturated fatty acids (UNS). Values are least squares means \pm SEM, $n=4$. The shaded background is a plot of eating rate (DM consumed per cow/min) over the sampling period, across treatments. Overall effects of treatment and time $\times$ treatment, respectively: CCK, $P<0.01, P=0.41$; GLP-1, $P=0.06, P=0.97$; ghrelin, $P=0.40, P=0.12$; †effect of fatty acid supplements vs. control, $P=0.07$. 
other classes of nutrients, suppress ghrelin secretion in the postprandial period (Overduin et al., 2005). However, our findings suggest that dietary FA may suppress the prandial ghrelin surge as well. This novel finding may be a result of treatment effects on CCK-8 concentration before feeding, because suppression of ghrelin secretion by duodenal infusion of long-chain FA was eliminated by administration of a CCK-1 receptor antagonist (Degen et al., 2007). Given the putative role of ghrelin in stimulating meal initiation, the effect of diet composition on this premeal surge is worthy of further investigation.

Taken as a whole, the enhancement of satiety-inducing gut peptides by UNS and the tendency for FA to suppress prandial ghrelin release suggests that depression of feed intake by UNS is mediated, at least in part, by gut peptide responses to dietary unsaturated FA. However, in dietary studies such as this, other potential mechanisms cannot be ruled out. In this study, UNS decreased milk fat secretion and milk energy output (Harvatine and Allen, 2006b), potentially decreasing the drive to eat. Unsaturated FA are also thought to promote lipid oxidation (Jones et al., 1992), which may stimulate satiety directly (Allen et al., 2005). Nevertheless, a CCK receptor antagonist prevented intake depression by a diet high in unsaturated FA for $2 \mathrm{~h}$ postinjection (Choi et al., 2000), providing strong support for CCK involvement in the intake response to dietary FA. Identification and use of other receptor antagonists may provide the means to better isolate the effects of gut peptides in the future.

\section{ACKNOWLEDGMENTS}

This work was partially supported by MSC Specialty Nutrition (Dundee, IL). The authors thank Y. Ying for technical assistance and R. J. Tempelman for advice on statistical analysis.

\section{REFERENCES}

Allen, M. S. 2000. Effects of diet on short-term regulation of feed intake by lactating dairy cattle. J. Dairy Sci. 83:1598-1624.

Allen, M. S., B. J. Bradford, and K. J. Harvatine. 2005. The cow as a model to study food intake regulation. Annu. Rev. Nutr. 25:523-547.

Allen, M. S., M. Oba, and C. S. Mooney. 2000. Automated system for collection of ruminal fluid and blood of ruminants. J. Dairy Sci. 83(Suppl. 1):288. (Abstr.)

Beardshall, K., G. Frost, Y. Morarji, J. Domin, S. R. Bloom, and J. Calam. 1989. Saturation of fat and cholecystokinin release: Implications for pancreatic carcinogenesis. Lancet 2:1008-1010.

Beglinger, C., and L. Degen. 2004. Fat in the intestine as a regulator of appetite-Role of CCK. Physiol. Behav. 83:617-621.

Benson, J. A., and C. K. Reynolds. 2001. Effects of abomasal infusion of long-chain fatty acids on splanchnic metabolism of pancreatic and gut hormones in lactating dairy cows. J. Dairy Sci. 84:1488-1500.
Beysen, C., F. Karpe, B. Fielding, A. Clark, J. Levy, and K. Frayn. 2002. Interaction between specific fatty acids, GLP-1 and insulin secretion in humans. Diabetologia 45:1533-1541.

Chelikani, P. K., D. R. Glimm, D. H. Keisler, and J. J. Kennelly. 2004. Effects of feeding or abomasal infusion of canola oil in Holstein cows. 2. Gene expression and plasma concentrations of cholecystokinin and leptin. J. Dairy Res. 71:288-296.

Choi, B.-R., and D. L. Palmquist. 1996. High fat diets increase plasma cholecystokinin and pancreatic polypeptide, and decrease plasma insulin and feed intake in lactating cows. J. Nutr. 126:2913-2919.

Choi, B. R., D. L. Palmquist, and M. S. Allen. 2000. Cholecystokinin mediates depression of feed intake in dairy cattle fed high fat diets. Domest. Anim. Endocrinol. 19:159-175.

Cummings, D. E., R. S. Frayo, C. Marmonier, R. Aubert, and D. Chapelot. 2004. Plasma ghrelin levels and hunger scores in humans initiating meals voluntarily without time- and food-related cues. Am. J. Physiol. Endocrinol. Metab. 287:E297-E304.

Dado, R. G., and M. S. Allen. 1993. Continuous computer acquisition of feed and water intake, chewing reticular motility, and ruminal pH of cattle. J. Dairy Sci. 76:1589-1600.

Deacon, C. F. 2004. Circulation and degradation of GIP and GLP-1. Horm. Metab. Res. 36:761-765.

Degen, L., J. Drewe, F. Piccoli, K. Grani, S. Oesch, R. Bunea, M. D'Amato, and C. Beglinger. 2007. Effect of CCK-1 receptor blockade on ghrelin and PYY secretion in men. Am. J. Physiol. Regul. Integr. Comp. Physiol. 292:R1391-R1399.

Douglas, B. R., J. B. Jansen, A. J. de Jong, and C. B. Lamers. 1990. Effect of various triglycerides on plasma cholecystokinin levels in rats. J. Nutr. 120:686-690.

Drackley, J. K., T. H. Klusmeyer, A. M. Trusk, and J. H. Clark. 1992. Infusion of long-chain fatty acids varying in saturation and chain length into the abomasum of lactating dairy cows. J. Dairy Sci. 75:1517-1526.

French, S. J., C. A. Conlon, S. T. Mutuma, M. Arnold, N. W. Read, G. Meijer, and J. Francis. 2000. The effects of intestinal infusion of long-chain fatty acids on food intake in humans. Gastroenterology 119:943-948.

Harvatine, K. J., and M. S. Allen. 2006a. Effects of fatty acid supplements on feed intake, and feeding and chewing behavior of lactating dairy cows. J. Dairy Sci. 89:1104-1112.

Harvatine, K. J., and M. S. Allen. 2006b. Effects of fatty acid supplements on milk yield and energy balance of lactating dairy cows. J. Dairy Sci. 89:1081-1091.

Harvatine, K. J., and M. S. Allen. 2006c. Effects of fatty acid supplements on ruminal and total tract nutrient digestion in lactating dairy cows. J. Dairy Sci. 89:1092-1103.

Harvatine, K. J., and M. S. Allen. 2006d. Fat supplements affect fractional rates of ruminal fatty acid biohydrogenation and passage in dairy cows. J. Nutr. 136:677-685.

Hirasawa, A., K. Tsumaya, T. Awaji, S. Katsuma, T. Adachi, M. Yamada, Y. Sugimoto, S. Miyazaki, and G. Tsujimoto. 2005. Free fatty acids regulate gut incretin glucagon-like peptide-1 secretion through GPR120. Nat. Med. 11:90-94.

Hopman, W. P., J. B. Jansen, and C. B. Lamers. 1984. Plasma cholecystokinin response to a liquid fat meal in vagotomized patients. Ann. Surg. 200:693-697.

Hornung, R. W., and L. D. Reed. 1990. Estimation of average concentration in the presence of nondetectable values. Appl. Occup. Environ. Hyg. 5:46-51.

Jenkins, T. C., and D. L. Palmquist. 1984. Effect of fatty acids or calcium soaps on rumen and total nutrient digestibility of dairy rations. J. Dairy Sci. 67:978-986.

Jones, P. J., J. E. Ridgen, P. T. Phang, and C. L. Birmingham. 1992. Influence of dietary fat polyunsaturated to saturated ratio on energy substrate utilization in obesity. Metabolism 41:396-401.

Laugerette, F., P. Passilly-Degrace, B. Patris, I. Niot, M. Febbraio, J. P. Montmayeur, and P. Besnard. 2005. CD36 involvement in orosensory detection of dietary lipids, spontaneous fat preference, and digestive secretions. J. Clin. Invest. 115:3177-3184.

Litherland, N. B., S. Thire, A. D. Beaulieu, C. K. Reynolds, J. A. Benson, and J. K. Drackley. 2005. Dry matter intake is decreased 
more by abomasal infusion of unsaturated free fatty acids than by unsaturated triglycerides. J. Dairy Sci. 88:632-643.

Mir, P. S., G. J. Mears, E. K. Okine, T. Entz, C. M. Ross, S. D. Husar, and Z. Mir. 2000. Effects of increasing dietary grain on viscosity of duodenal digesta and plasma hormone, glucose and amino acid concentrations in steers. Can. J. Anim. Sci. 80:703-712.

Morgan, C. R., and A. Lazarow. 1963. Immunoassay of insulin: Two antibody system. Plasma insulin levels in normal, subdiabetic, and diabetic rats. Diabetes 12:115-126.

Overduin, J., R. S. Frayo, H. J. Grill, J. M. Kaplan, and D. E. Cummings. 2005. Role of the duodenum and macronutrient type in ghrelin regulation. Endocrinology 146:845-850.

Palmquist, D. L., and T. C. Jenkins. 1980. Fat in lactation rations: Review. J. Dairy Sci. 63:1-14.

Relling, A. E., and C. K. Reynolds. 2007. Feeding rumen-inert fats differing in their degree of saturation decreases intake and increases plasma concentrations of gut peptides in lactating dairy cows. J. Dairy Sci. 90:1506-1515.

Rocca, A. S., J. LaGreca, J. Kalitsky, and P. L. Brubaker. 2001. Monounsaturated fatty acid diets improve glycemic tolerance through increased secretion of glucagon-like peptide-1. Endocrinology 142:1148-1155.

Schauff, D. J., and J. H. Clark. 1992. Effects of feeding diets containing calcium salts of long-chain fatty acids to lactating dairy cows. J. Dairy Sci. 75:2990-3002.
Sugino, T., J. Yamaura, M. Yamagishi, A. Ogura, R. Hayashi, Y. Kurose, M. Kojima, K. Kangawa, Y. Hasegawa, and Y. Terashima. 2002. A transient surge of ghrelin secretion before feeding is modified by different feeding regimens in sheep. Biochem. Biophys. Res. Commun. 298:785-788.

Thomsen, C., O. Rasmussen, T. Lousen, J. J. Holst, S. Fenselau, J. Schrezenmeir, and K. Hermansen. 1999. Differential effects of saturated and monounsaturated fatty acids on postprandial lipemia and incretin responses in healthy subjects. Am. J. Clin. Nutr. 69:1135-1143

Thomsen, C., H. Storm, J. J. Holst, and K. Hermansen. 2003. Differential effects of saturated and monounsaturated fats on postprandial lipemia and glucagon-like peptide 1 responses in patients with type 2 diabetes. Am. J. Clin. Nutr. 77:605-611.

Wertz-Lutz, A. E., T. J. Knight, R. H. Pritchard, J. A. Daniel, J. A. Clapper, A. J. Smart, A. Trenkle, and D. C. Beitz. 2006. Circulating ghrelin concentrations fluctuate relative to nutritional status and influence feeding behavior in cattle. J. Anim. Sci. 84:32853300 .

Wisen, O., H. Bjorvell, P. Cantor, C. Johansson, and E. Theodorsson. 1992. Plasma concentrations of regulatory peptides in obesity following modified sham feeding (MSF) and a liquid test meal. Regul. Pept. 39:43-54. 